\title{
A Gastronomia Hospitalar como Instrumento de Humanização
}

\author{
Nakasato, Miyoko; Casseb, Mariana Otani; Costa, Helenice Moreira da; Cardoso, \\ Elisabeth
}

Instituto do Coração do Hospital das Clínicas da Faculdade de Medicina da Universidade de São Paulo _ miyoko.nakasato@incor.usp.br

Introdução: a alimentação hospitalar é reconhecida por sua importância no atendimento às necessidades físicas e nutricionais dos pacientes. Porém, existe uma vulnerabilidade da aceitação da dieta hospitalar quando esta é baseada apenas em conhecimentos técnico-científicos. Assim, o cuidado humanizado, no que tange à alimentação, envolve os aspectos nutricionais e higiênico-sanitários, mas também o cuidado, conforto, acolhimento e as dimensões simbólicas e sensoriais da alimentação. a dieta hospitalar, que antes era vista como monótona, insípida e de odor desagradável, hoje recebe o incremento da gastronomia e de técnicas culinárias adaptadas às restrições dietéticas dos pacientes internados, com a finalidade de tornar as refeições nutricionalmente equilibradas e ao mesmo tempo prazerosas. a humanização da alimentação hospitalar deve integrar aspectos éticos que visem o atendimento individualizado; a prestação de um serviço de qualidade através do atendimento às expectativas do paciente; as sensações despertas pelo sabor, aroma, cor, temperatura e textura dos alimentos; e os aspectos simbólicos e afetivos representados pelo ato de se alimentar, que envolvem o convívio, a troca de experiências, as comemorações e o respeito aos hábitos culturais e alimentares de cada indivíduo. Objetivos: descrever as ações humanizadoras na área da alimentação e gastronomia de um Serviço de Nutrição e Dietética de um hospital público especializado em cardiopneumologia de São Paulo. Métodos: Levantamento das ações humanizadoras implantadas nos últimos 10 anos. Resultados: Faz parte das ações de humanização, a elaboração de cardápios especiais para Natal e Ano Novo, utilizando preparações típicas e alimentos diferenciados, com decoração de temas natalinos nas bandejas, tornando a refeição um momento especial. o dia das crianças é outra data lembrada pelo serviço, com o intuito de levar um pouco de alegria às crianças internadas, oferecendo preparações como bolos, doces ou cachorro quente. Além desses momentos especiais, o serviço preocupa-se em oferecer diariamente um cardápio variado, colorido, nutricionalmente adequado e priorizando o uso de temperos naturais. Há também, a aplicação do conceito de comfort food, atendendo as solicitações de pedidos especiais, uma vez que o nutricionista clínico presta atendimento nutricional ao paciente considerando os hábitos, as preferências e as aversões alimentares. Conclusão: a gastronomia é uma importante ferramenta na implantação de um serviço humanizado, contribuindo para o tratamento e conforto do paciente durante o período de internação, tornando-se uma importante aliada no processo de recuperação.

Nakasato, Miyoko; Casseb, Mariana Otani; Costa, Helenice Moreira da; Cardoso, Elisabeth. A Gastronomia Hospitalar como Instrumento de Humanização. In: Anais do Congresso Internacional de Humanidades \& Humanização em Saúde [= Blucher Medical Proceedings, num.2, vol.1]. São Paulo: Editora Blucher, 2014. ISSN 2357-7282

DOI 10.5151/medpro-cihhs-10326 